\title{
Kebijakan Inovasi Teknologi Bidang Perikanan Bagi Masyarakat Transmigrasi Lokal Di Kecamatan Xiii Koto Kampar Kabupaten Kampar
}

\author{
Adinda Qori T.M ${ }^{* 1}$, Meyzi Heriyanto ${ }^{2}$, Febri Yuliani ${ }^{3}$ \\ Program Studi Pascasarjana Ilmu Administrasi Publik Universitas Riau
}

Korespondensi: dinda.qori21@gmail.com

\begin{abstract}
Abstrak
Penelitian ini dilatar belakangi Kabupaten Kampar merupakan salah satu daerah yang mengeluarkan kebijakan terkait Kawasan Minopolitan, yaitu di Desa Koto Mesjid. Pemerintah Daerah Kabupaten Kampar menuangkan kebijakan daerahnya dalam bentuk Keputusan Bupati Kabupaten Kampar dalam memfasilitasi desa tersebut sebagai wilayah cluster yang terbit dalam tiga bentuk kebijakan. Kawasan Minapolitan merupakan konsepsi pembangunan ekonomi kelautan perikanan berbasis kawasan berdasarkan prinsip-prinsip terintegrasi, efisiensi, berkualitas serta percepatan. Kawasan Minapolitan merupakan suatu bagian wilayah yang memiliki fungsi utama ekonomi yang terdiri dari sentra produksi, pengolahan, pemasaran komoditas perikanan, pelayanan jasa, dan/atau kegiatan pendukung lainnya. Penelitian ini bertujuan untuk mengetahui bagaimana kebijakan inovasi teknologi bidang perikanan bagi masyarakat transmigrasi lokal di desa koto masjid dapat berlangsung serta apa saja faktor yang pendukung dan penghambat dalam penerapan kebijakan inovasi teknologi bidang perikanan bagi masyarakat transmigrasi local di Desa Koto Masjid. Penelitian ini menggunakan pendekatan kualitatif deskriptif dan peneliti menetapkan prosedur sampling purposive mana yang dapat digunakan untuk mengindentifikasi orangorang yang akan diobservasi atau diwawancarai dengan teknik pengumpulan data berupa observasi, wawancara dan dokumentasi kemudian dianalisis dengan teknik trigualasi. HasiI penelitian ini menunjukkan Kebijakan inovasi teknologi bidang perikanan bagi masyarakat transmigrasi lokal di kecamatan XIII Koto Kampar Kabupaten Kampar sebagai kawasan sentra produksi perikanan di provinsi Riau melalui surat Keputusan Gubernur Riau No. KPTS/99/II/2000 tanggal 28 Februari 2000 dan baru tahun 2010 ditetapkan sebagai kawasan Minapolitan dapat dijadikan salah satu alternative solusi dalam mewujudkan visi dan misi Kabupaten Kampar tersebut serta penelitian ini memiliki faktor pendukung yakni konsep awal kebijakan, sumber daya dan kemandirian masyarakat pembudidaya dan faktor penghambatnya yaitu peran pemerintah, koordinasi dan komunikasi birokrasi, dan evaluasi jangka waktu maka tujuan dari pelaksanaan kebijakan ini masih belum dapat tercapai dengan maksimal.
\end{abstract}

Kata Kunci: Kebijakan, Inovasi, Kawasan Minapolitan

Abstract
The background of this research is that Kampar Regency is one of the areas that issued policies related to the Minopolitan Region, namely in the Koto Mesjid Village. The Regional Government of Kampar Regency sets out its regional policies in the form of a Decree of the Regent of Kampar Regency in facilitating the village as a cluster area which is published in three forms of policy. The Minapolitan area is an area-based conception of marine and fisheries economic development based on the principles of integration, efficiency, quality and acceleration. Minapolitan area is a part of the area that has the main economic function consisting of production centers, processing, marketing of fishery commodities, services, and/or other supporting activities. This study aims to find out how the technological innovation policy in the field of fisheries for local transmigration communities in the village of Koto Masjid can take place and what are the supporting and inhibiting factors in the application of technological innovation policies in the field of fisheries for local transmigration communities in Koto Masjid Village. This study uses a descriptive qualitative approach and the researcher determines which purposive sampling procedure can be used to identify the people who will be observed or interviewed with data collection techniques in the form of observation, interviews and documentation and then analyzed with trigualation techniques. The results of this study indicate the policy of technological innovation in the field of fisheries for local transmigration communities in the XIII district of Koto Kampar, Kampar Regency as a fishery production center in 
Riau province through the Decree of the Governor of Riau No. KPTS/99/II/2000 dated February 28, 2000 and only in 2010 was designated as a Minapolitan area can be used as an alternative solution in realizing the vision and mission of Kampar Regency and this research has supporting factors, namely the initial concept of policy, resources and independence of the cultivating community. and the inhibiting factors are the government's role, bureaucratic coordination and communication, and evaluation of the time period, so the objectives of implementing this policy have not been maximally achieved.

Keywords: Policy, Innovation, Minapolitan Area

\section{PENDAHULUAN}

Konsep dasar pengembangan Kawasan Minapolitan adalah upaya menciptakan pembangunan inter-regional berimbang, khususnya dengan meningkatkan keterkaitan pembangunan kota-desa (ruralurban linkage) yaitu pengembangan kawasan perdesaan yang terintegrasi di dalam sistem perkotaan secara fungsional dan spasial. Pengembangan ekonomi masyarakat lokal/perdesaan sangat penting, dengan diupayakan optimalisasi pemanfaatan sumberdaya lokal melalui pengembangan ekonomi komunitas, investasi social capital dan human capital, investasi di bidang prasarana dan sumberdaya alam (natural capital). Pengembangan kawasan Minapolitan dilakukan dengan disertai upaya peningkatan capacity building di tingkat masyarakat maupun di tingkat pemerintahan agar menjamin manfaat utama dapat dinikmati masyarakat lokal. Dalam Undang-Undang No. 26 Tahun 2007 tentang Penataan Ruang, Minapolitan masuk dalam kategori Agropolitan dijelaskan bahwa Kawasan Agropolitan/Minapolitan adalah kawasan yang terdiri atas satu atau lebih pusat kegiatan pada wilayah perdesaan sebagai sistem produksi pertanian/perikanan dan pengelolaan sumber daya alam tertentu yang ditunjukkan oleh adanya keterkaitan fungsional dan hirarki keruangan satuan sistem permukiman dan sistem agrobisnis. Dijelaskan pula pada pasal 26 bahwa rencana tata ruang kawasan perdesaan merupakan bagian dari rencana tata ruang wilayah kabupaten yang dapat disusun sebagai instrument pemanfaatan ruang untuk mengoptimalkan kegiatan pertanian/perikanan, yang dapat berbentuk kawasan agropolitan/Minapolitan.

Keputusan Menteri Kelautan dan Perikanan Republik Indonesia Nomor: 35/Kepmen-KP/2013 tentang Penetapan Kawasan Minapolitan. Dukungan kebijakan yang dilakukan membuat Desa Koto Mesjid menjadi salah satu daerah cluster bagi pengembangan bidang perikanan. Penetapan wilayah Desa Koto Mesjid menjadi cluster Kawasan Minapolitan semakin memberikan efek positif bagi peningkatan kesejaheteraan masyarakatnya. Sebab dengan adanya penetapan Kawasan Minapolitan ini, Desa Koto Mesjid diberikan fasilitas sarana dan prasarana untuk mengembangkan bahan baku komoditi ikan patin menjadi produk. Seiring dengan berjalannya waktu, masyarakat mulai secara bertahap mengikuti inovasi teknologi berbudidaya ikan patin sebagai sumber pendapatan baru bagi kehidupannya. Adopsi inovasi teknologi yang dilakukan oleh masyarakat secara berlahan menggiring mereka untuk keluar dari kemiskinan yang dihadapinya. Masyarakat Desa Koto Mesjid merupakan masyarakat transmigrasi lokal yang terbentuk akibatnya adanya pembangunan yang dilaksanakan oleh Pemerintah Daerah.

Luas wilayah Desa Koto Masjid adalah 425,5 ha. Berupa daratan yang bertopografi perbukitan. Daratan dimanfaatkan sebagai lahan perikanan (kolam darat). Iklim desa Koto Masjid, sebagaimana desadesa lain yang ada di indonesia mempunyai iklim kemarau dan penghujan, hal tersebut mempunyai pengaruh langsung terhadap usaha perikanan yang ada di Desa Koto Masjid, Kecamatan XIII Koto Kampar. Kondisi lingkungan Desa Koto Masjid merupakan wilayah yang berada di pingiran waduk PLTA Koto Panjang. Hal ini menjadikan Desa Koto Masjid, selain sebagai pusat pengembangan perikanan kolam darat, juga berpotensi dalam pengembangan keramba jaring apung (KJA) di waduk PLTA Koto Panjang. Desa Koto Mesjid adalah nama desa yang terletak di Wilayah Kecamatan XIII Koto 
Kampar, Kabupaten Kampar, Provinsi Riau. Nama dari Koto Mesjid diambil dari nama sebuah dusun atau kampung yang pertama berdiri semasa Koto Mesjid masih bergabung dengan desa induknya, yaitu Desa Pulau Gadang, sebelum terjadinya pemekaran desa. Desa Koto Mesjid merupakan desa pemekaran dari Desa Pulau Gadang berdasarkan Keputusan Gubernur Riau Nomor 247 Tahun 1999. Saat awal dimekarkan, desa tersebut hanya memiliki 343 kepala keluarga dengan 1.239 jiwa penduduk. Namun, setelah mekar selama \pm 18 tahun, perkembangan desa cukup pesat karena saat ini desa memiliki 2.299 jiwa penduduk dan 717 kepala keluarga. Jumlah ini dapat digolongkan berdasarkan kelompok umur dan jenis ke/lamin, seperti tampak pada Grafik 1.1 berikut ini

Grafik 1.1

Jumlah Masyarakat Desa Koto Mesjid Berdasarkan Kelompok Umur dan Jenis Kelamin

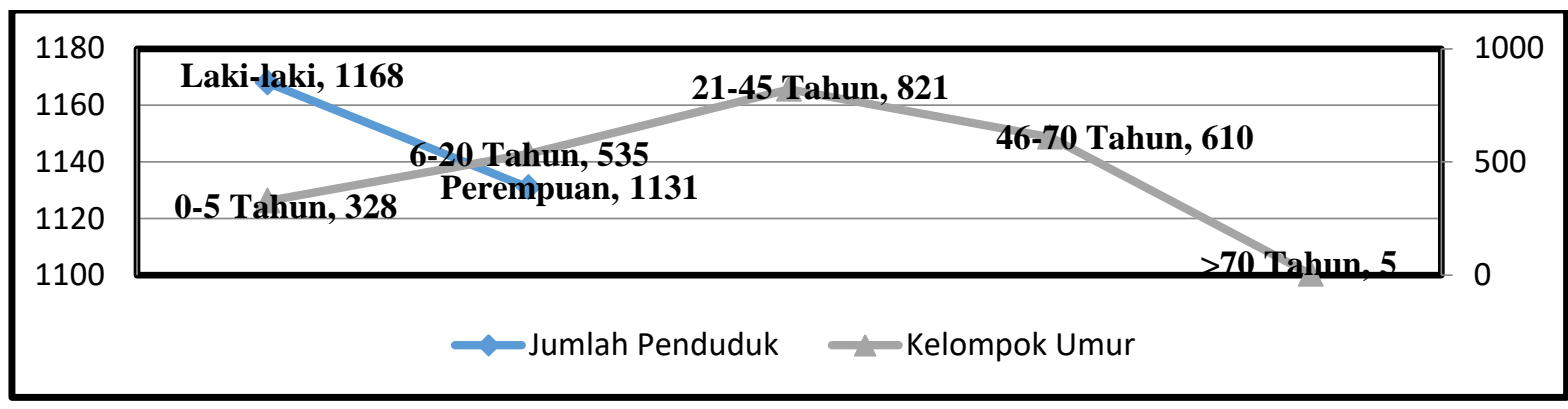

Sumber: Desa Koto Mesjid, 2019

Menjelaskan bahwa kelompok umur masyarakat didominasi oleh rentang umur 21-45 tahun yang berjumlah 821 jiwa atau 35,7 persen. Fakta itu menunjukkan bahwa mayoritas masyarakat di desa termasuk kategori rentang umur yang sangat produktif dalam bekerja. Hal itu karena untuk melaksanakan pekerjaan sebagai seorang pembudidaya ikan dan petani karet membutuhkan kondisi fisik kuat dan sehat. Kondisi sosial ekonomi masyarakat merupakan aktivitas masyarakat yang dilakukan dalam berbagai bidang kehidupan, yaitu pendidikan, kesehatan, keagamaan dan etnis, serta ekonomi. Bidang pendidikan merupakan faktor yang penting untuk menunjang kehidupan masyarakat di suatu wilayah. Untuk mengetahui tingkat pendidikan di Desa Koto Mesjid, dapat dilihat pada Grafik 1.2 berikut.

Grafik 1.2

Tingkat Pendidikan Masyarakat di Desa Koto Mesjid

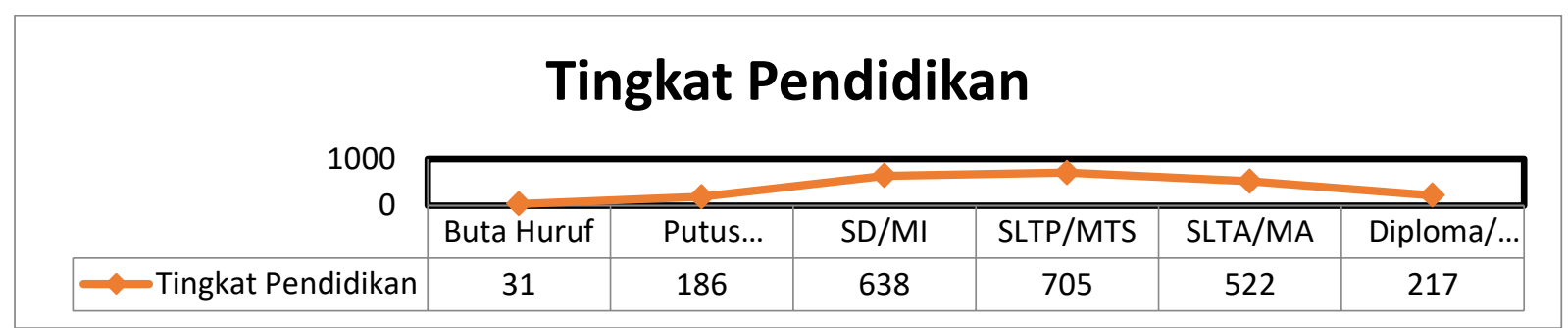

Sumber : Desa Koto Mesjid, 2019

Tingkat pendidikan masyarakat pada dasarnya masih rendah karena masih didominasi oleh tingkat pendidikan SLTP/MTS (30,7 Persen). Untuk mengetahui kegiatan di bidang ekonomi atau mata pencaharian masyarakat, dapat dilihat pada Grafik 1.3 berikut ini. 


\section{Grafik 1.3}

Mata Pencaharian Masyarakat di Desa Koto Mesjid

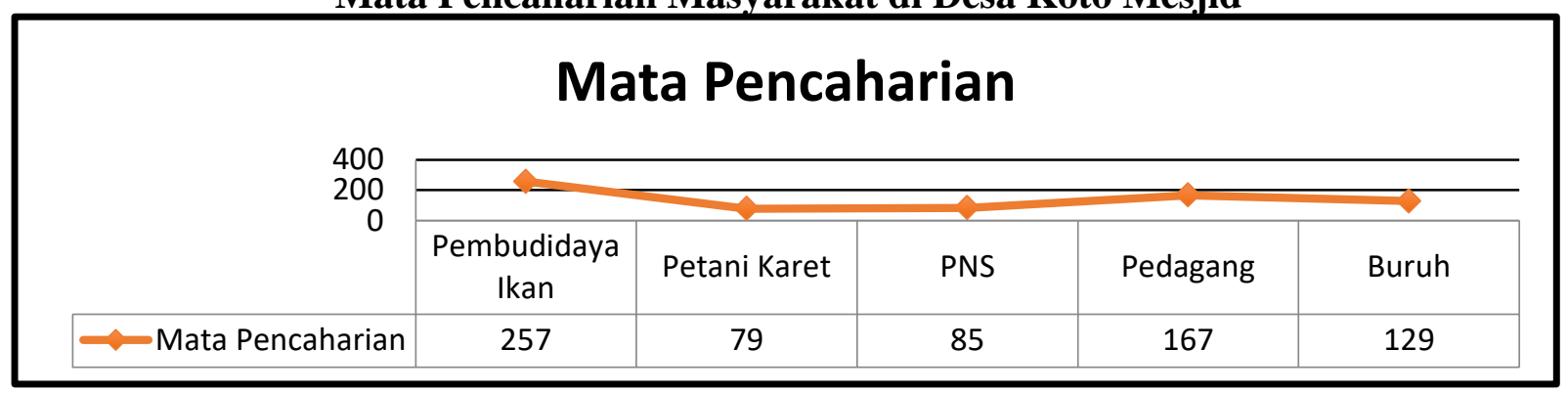

Sumber : Desa Koto Mesjid, 2019

Mayoritas aktivitas ekonomi yang cenderung digeluti oleh masyarakat adalah sebagai pembudidaya ikan patin. Hal ini karena budidaya ikan kolam merupakan alternatif pertama yang ditemukan oleh masyarakat sebagai penganti mata pencaharian utama sebelumnya sebagai seorang petani karet. Fakta itu juga disebabkan oleh mata pencaharian masyarakat sebelum direlokasi sebagai transmigrasi lokal merupakan pencari ikan di sungai. Proses adopsi inovasi teknologi yang dilakukan oleh masyarakat untuk menjadi pembudidaya ikan kolam awalnya tidak berjalan dengan lancar. Namun desakan ekonomi yang terus memaksa masyarakat untuk segera menemukan mata pencaharian baru. Hingga akhirnya inovasi teknologi budidaya komoditas ikan patin dapat dibuktikan dan memberikan janji keuntunga, barulah secara bertahap masyarakat mengadopsinya dan berhasil. Keberhasilan masyarakat yang mencoba berbudidaya ikan patin akhirnya secara bertahap meyakinkan masyarakat lainya untuk mengadopsi inovasi teknologi budidaya ikan patin. Hingga akhirnya hampir \pm 80 persen masyarakat saat ini menggantungkan ekonomi dan mata pencahariannya dengan berbudidaya ikan patin.

Fenomena terhadap kebijakan kawasan minopolitan di kabupaten Kampar adalah proses penyesuaian. Fenomena ini berlangsung pada masa-masa awal di tetapkannya daerah tersebut sebagai kawasan minopolitan. Pemerintah melakukan edukasi dengan mengirimkan tenaga ahli minopolitan sehingga dapat menjadi pembimbing masyarakat terhadap penerapan kebijakan tersebut. Hal ini berlangsung efektif sehingga masyarakat dapat menjalankan konsep kawasan minopolitan yang di tetapkan oleh pemerintah. Kawasan ini terbukti berhasil dan menjadi salah satu sentra produksi dengan jumlah panen yang cukup menjanjikan. Sehingga mendapatkan julukan sebagai kampung Patin.

Konsep kebijakan menuut Carl J Federick sebagaimana dikutip Leo Agustino (2008:7) kebijakan sebagai serangkaian tindakan/kegiatan yang diusulkan seseorang, kelompok atau pemerintah dalam suatu lingkungan tertentu dimana terdapat hambatan-hambatan (kesulitan-kesulitan) dan kesempatankesempatan terhadap pelaksanaan usulan kebijaksanaan tersebut dalam rangka mencapai tujuan tertentu. Menurut Thomas R. Dye dan James Anderson dalam Agustino (2006:38) ada tiga alasan yang melatar belakangi mengapa kebijakan publik perlu untuk dipelajari. Pertama, pertimbangan ilmiah (scientific reason). Kedua, pertimbangan professional (professional reasons). Ketiga, pertimbangan politis (political reason).

Literatur modern menjelaskan bahwa inovasi sendiri memiliki pengertian yang sangat beragam serta banyak perspektif yang mencoba memaknainya. Salah satu pengertian menyebutkan bahwa inovasi adalah kegiatan yang meliputi seluruh proses menciptakan dan menawarkan jasa atau barang baik yang sifatnya baru, lebih baik atau lebih murah dibandingkan dengan yang tersedia sebelumnya. Pengertian ini menekankan pemahaman inovasi sebagai sebuah kegiatan (proses) penemuan (invention). Sebuah inovasi dapat berupa produk atau jasa yang baru, teknologi proses produksi yang baru, sistem struktur dan administrasi baru atau rencana baru bagi anggota organisasi. Menurut Rogers (2003), salah satu penulis 
buku inovasi terkemuka, menjelaskan bahwa: "an innovation is an idea, practice, or object that is perceived as new by individual or other unit of adopter". Jadi inovasi adalah sebuah ide, praktek, atau objek yang dianggap baru oleh individu satu unit adopsi lainnya. Inovasi dapat merupakan sesuatu yang berwujud (tangible) maupun sesuatu yang tidak berwujud (intangible). Memaknai inovasi sebagai sesuai yang hanya identik dengan teknologi saja akan jadi menyempitkan konteks inovasi yang sebenarnya.

Inovasi juga dapat didefinisikan sebagai suatu perubahan (ide besar) dalam sekumpulan informasi yang berhubungan di antara masukan dan keluaran. Dari definisi tersebut didapatkan dua hal, yaitu inovasi proses dan inovasi produk. Hal inilah yang membedakannya dengan invensi (invention) atau temuan yang merupakan suatu gagasan atau model dari pengembangan suatu produk atau proses (solusi masalah). Sebagai ilustrasi, ilmu mengenal kata invensi, dan inovasi adalah dalam konteks perubahan, yaitu:

1. Invensi dapat digambarkan suatu kumpulan kreatif dari teknologi yang ada untuk membuat suatu produk yang belum ada sebelumnya.

2. Inovasi (pembaharuan) adalah suatu kumpulan dari teknologi dan ilmu yang ada untuk memenuhi kebutuhan tertentu. Inovasi ini menitikberatkan pada jangka pendek dan menengah, serta tidak memerlukan terobosan teknik. Selain itu, inovasi memerlukan faktor-faktor terpilih dari suatu pengetahuan untuk dipadukan secara unik, agar diperoleh keuntungan pada seluruh produk atau proses yang ada.

\section{Gambar 2.1}

\section{Konsep Inovasi sebagai Suatu Bentuk Kemajuan Teknologi}

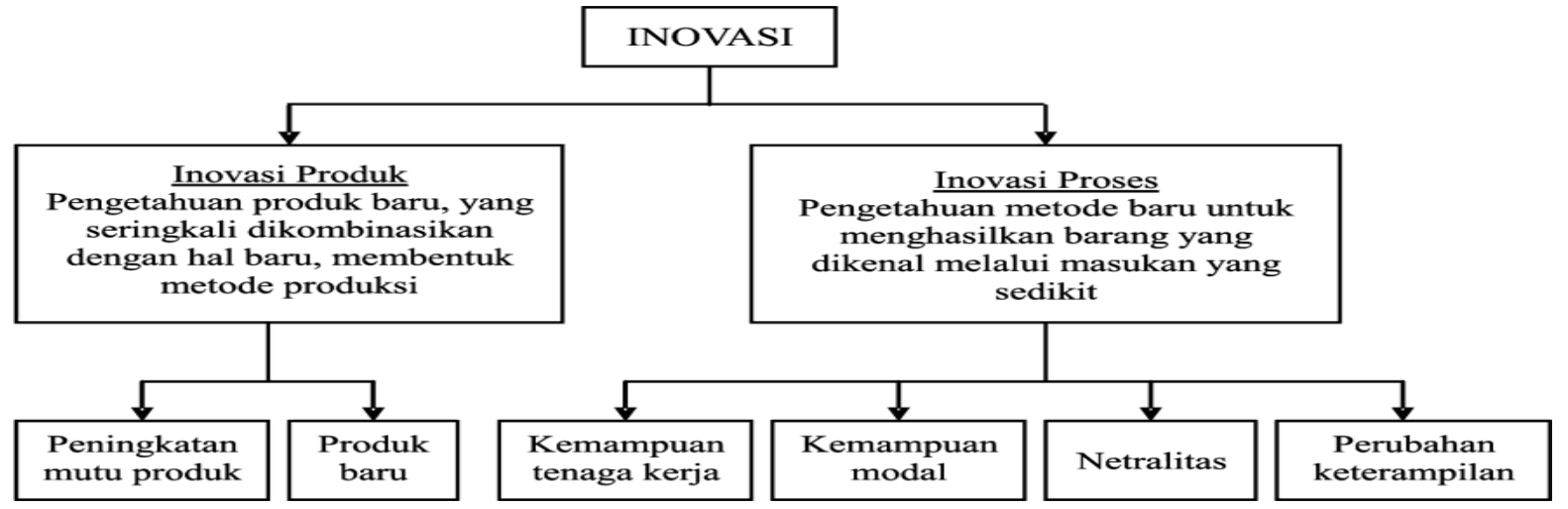

Sumber : Hubeis, 2005

Proses inovasi berdasarkan pola pikir ilmiah dapat dianggap sebagai inovasi pola pikir deduktif (besar ke kecil) ke pola pikir induktif (kecil ke besar) yang diawali dari gagasan tertentu (model) dan diakhiri oleh suatu perwujudan fisik dan atau non fisik (indikator). Kebijakan Inovasi Teknologi Bidang Perikanan Bagi Masyarakat Transmigrasi Lokal Menurut Suharno (2010:31) :

a. Tujuan yang akan dicapai

Tujuan diperlukan untuk mengarahkan dalam perumusan kebijakan, yang dimaksud tujuan dalam penelitian ini yaitu dengan ditetapkannya Kecamatan XIII Koto Kampar sebagai salah satu kawasan Minapolitan yang ada di Provinsi Riau, hal tersebut dilakukan agar dapat meningkatkan ekonomi masyarakat skala mikro dan kecil dan meningkatkan sektor perikanan sebagai penggerak ekonomi secara regional maupun nasional.

b. Preferensi nilai yang dipertimbangkan

Preferensi nilai adalah sebuah konsep dalam suatu kebijakan yang merupakan landasan atau penuntun dalam pengambilan keputusan kebijakan. Preferensi nilai yang dimaksud dalam penelitian ini dimana pemerintah Kabupaten Kampar melihat masyarakat Desa Koto Mesjid yang 
mana sebagian masyarakatnya adalah pembudidaya sektor perikanan. Kebijakan kawasan minopolitan yang merupakan suatu dasar aturan terhadap kawasan minopolitan dalam perkembangannya membutuhkan penyesuaian agar capaian yang diharapkan terlaksana dengan baik dan terukur.

c. Sumber daya pendukung kebijakan

Sumber daya pendukung kebijakan yang dimaksud dalam penelitian ini adalah merupakan keberhasilan proses pelaksanaan kebijakan kawasan minapolitan yang dipengaruhi dengan pemanfaatan sumber daya manusia, biaya, dan waktu.

d. Kemampuan aktor yang terlibat dalam pembuatan kebijakan

Kemampuan aktor yang dimaksud dalam penelitian ini adalah kualitas dari kebijakan kawasan minapolitan di Kabupaten Kampar dipengaruhi oleh kemampuan dari para aktor pembuat kebijakan, kualitas yang dimaksud tersebut adalah dari segi tingkat pendidikan, kompetensi dalam bidangnya, pengalaman kerja, dan integritas moralnya

e. Lingkungan

Lingkungan yang dimaksud dalam penelitian ini adalah kualitas dari suatu kebijakan kawasan minapolitan akan dipengaruhi oleh konteks sosial, ekonomi, maupun politik di Desa Koto Mesjid Kecamatan XIII Koto Kampar. Lingkungan ekonomi, sosial dan politik juga merupakan faktor yang menentukan keberhasilan suatu kebijakan.

\section{METODE}

Penelitian kualitatif memiliki tahapan penelitian yang melampaui berbagai tahapan berfikir kritis ilmiah, yang mana seorang peneliti mulai berfikir secara induktif yaitu menangkap berbagai fakta atau fenomena-fenomena sosial melalui pengamatan di lapangan, kemudian menganalisisnya dan berupaya melakukan teorisasi berdasarkan apa yang diamati itu. Dimana peneliti diarahkan oleh produk berfikir induktif untuk menemukan jawaban logis terhadap apa yang sedang menjadi pusat perhatian dalam penelitian dan akhirnya produk berfikir induktif menjadi jawaban sementara terhadap apa yang dipertanyakan dalam penelitian dan yang menjadi perhatian itu (Burhan Bungin, 2011). Pendekatan penelitian kualitatif yang dipilih adalah pendekatan studi kasus. Prosedur sampling purposive mana yang dapat digunakan untuk mengindentifikasi orang-orang yang akan diobservasi atau diwawancarai. Adapun yang menjadi informan yang akan memberikan keterangan tambahan demi mendapatkan data yang utuh dalam penelitian ini adalah instansi pemerintah yang terlibat dalam pengembangan inovasi yaitu Kepala Dinas Perikanan Kabupaten Kampar, Camat Kecamatan XIII Koto Kampar, Kepala Desa Koto Mesjid dan Masyarakat pembudidaya ikan patin di Desa Koto Mesjid. Penelitian ini dilaksanakan di Desa Koto Mesjid Kecamatan XIII Koto Kampar Kabupaten Kampar Provinsi Riau. Setalah data terkumpul dari setiap infoman penelitian, kemudian akan digunakan metode triangulasi dengan cek and cross cek terhadap hasil tanggapan yang diberikan informan penelitian. Salah satu cara paling penting dan mudah dalam uji keabsahan hasil penelitian adalah dengan melakukan triangulasi. 


\section{HASIL DAN PEMBAHASAN}

\subsection{Kebijakan Inovasi Teknologi Bidang Perikanan Bagi Masyarakat Transmigrasi Lokal di Kecamatan XIII Koto Kampar Kabupaten Kampar.}

Untuk menganalisa kebijakan inovasi teknologi bidang perikanan bagi masyarakat transmigrasi lokal di kecamatan XIII Koto Kampar Kabupaten Kampar yang akan dianalisa oleh penulis dalam tulisan ini. Penulis menggunakan indikator kebijakan inovasi teknologi bidang Perikanan bagi Masyarakat Transmigrasi Lokal yang dikemukan oleh Suharno. Untuk melihat capaian dari kebijakan yang telah ada dengan menggunakan 6 indikator, yaitu : Tujuan yang akan dicapai, Preferensi nilai yang dipertimbangkan, Sumber daya pendukung kebijakan, Kemampuan aktor yang terlibat dalam pembuatan kebijakan, Lingkungan dan Strategi yang digunakan.

\section{Tujuan yang akan di capai}

Tujuan yang akan di capai menekankan kepada visi dari sebuah pelaksanaan program dengan tolak ukur dari target yang diharapkan. Maksud dari tujuan yang akan di capai pada penelitian ini adalah bagaimana kondisi di lapangan terhadap capaian dari tujuan itu sendiri. Hal ini diharapkan dapat menjadi bentuk evaluasi terhadap pelaksanaan program minapolitan yang ada di kecamatan XIII Koto Kampar Kabupaten Kampar. Perikanan menunjukan bahwa program minopolitan tetap berjalan namun belum sesuai harapan karena pada birokrasi tingkat atas kurang memberikan perhatian kepada program minopolitan itu sendiri. Hal ini berdampak kepada tujuan yang ingin di capai dari program minopolitan tersebut. Kondisi dilapangan menunjukan bahwa hal ini belum terealisasikan secara menyeluruh sehingga tujuan yang akan di capai tidak dapat berjalan baik.

\section{Prefererensi Nilai}

Kondisi dimana sebuah kebijakan memiliki faktor yang kuat untuk menjadi prioritas dalam implementasinya. Preferensi menentukan sejauh mana sebuah kebijakan dapat berjalan dengan dinamika yang ada di lapangan. Faktor ini cukup penting karena sebuah kebijakan tidak dapat berjalan baik jika aktor pengambil keputusan tidak menjadikan kebijakan tersebut sebagai sebuah prioritas. Menunjukan bahwa preferensi nilai yang dipertimbangkan dalam program ini belum sesuai harapan dikarenakan kerjasama yang terjalin antara pemerintah dan masyarakat masih pasif.

\section{Sumber daya pendukung kebijakan}

Sumber daya pendukung merupakan subjek penting dalam berjalanya sebuah kebijakan/program. Sumber daya pendukung dapat juga diartikan sebagai kelayakan sebuah kebijakan untuk dilaksanakan dalam konteks inovasi. Hal ini dikarenakan kebutuhan sumber daya secara khusus untuk dapat menjalankan sebuah inovasi di lapangan. Kecamatan XIII Koto Kampar sendiri memiliki sumber daya yang sangat mencukupi baik dari sumber daya alam dan sumber daya manusianya sendiri. Sumber daya alam yang terdapat pada daerah ini sudah teruji hingga saat ini bahkan terus dikembangkan hingga pada pengembangan wisata perikanan. Sumber daya manusia yang terdapat di daerah ini menurut penulis juga cukup mumpuni terhadap kebijakan ini. Secaara proses, masyarakat XIII Koto Kampar telah melalui proses yang cukup Panjang dalam menjalankan kebijakan ini sehingga telah membentuk karakter yang sangat baik dengan adanya potensi yang terus dikembangkan. Kondisi ini tentunya menjadi hal yang sangat baik sehingga penulis mengasumsikan bahwa masyarakat akan terus produktif dengan potensi yang dimiliki dan dengan pola piker serta persaingan sehat yang menjadikan masyarakat terus meningkatkan kualitas baik dari seumber daya alam dan sumber daya manusia.

\section{Kemampuan aktor yang terlibat dalam pembuatan kebijakan}

Aktor merupakan bagian yang sangat penting dalam pembuatan kebijakan. Kemampuan aktor menentukan kualitas dari kebijakan, tolak ukur kebijakan, berhasil atau tidaknya sebuah kebijakan dapat dijalankan dan segala hal yang terkait dengan kelayakan sebuah kebijakan tepat sasaran dan 
berkelanjutan. Kemampuan aktor tentunya memiliki keterbatasan dalam pelaksanaanya. Fenomena birokrasi masa kini yang dinamis menjadikan faktor ini krusial untuk di analisa. Seorang aktor dapat dikatakan memiliki kemampuan jika telah melalui dan memiliki banyak pengalaman terkait hal yang di pelajarinya. Dinamika ini yang penulis anggap cukup kompleks karena bentuk kebijakan minapolitan yang memiliki jangka waktu Panjang kerap kali terbenturkan dengan perubahan-perubahan yang terjadi baik di tingkat atas maupun bawah. Kondisi ini harus dapat kita pahami secara baik agar dapat di evaluasi secara terukur terkait kemampuan aktor agar tidak mempengaruhi berjalannya kebijakan.

\section{Lingkungan}

Lingkungan adalah Kawasan dimana kebijakan di implementasikan. Lingkungan merupakan faktor yang berpengaruh besar terhadap sebuah kebijakan dan berdampak langsung terhadap berlangsungnya kebijakan. Lingkungan kecamatan XIII Koto Kampar merupakan lingkungan yang telah disiapkan menjadi Kawasan minapolitan, sehingga faktor ini sangat sesuai dengan kebijakan minapolitan yang dikeluarkan.Faktor lingkungan yang penulis amati dalam observasi dan wawancara dengan narasumber adalah fenomena dimana limbah dari produksi ikan patin di Kawasan tersebut mulai meresahkan masyarakat. Kondisi ini menjadi salah satu evaluasi terhadap kebijakan yang telah ada untuk di perbaiki di masa selanjutnya. Hal ini sangatlah penting demi keberlangsungan lingkungan miapolitan yang berkelanjutan. Sehingga tidak meresahkan aspek lingkungan yang sangat berpengaruh pada kebijakan ini. Kondisi ini menurut pandangan penulis merupakan sebuah tingkatan yang sangat baik dalam menjalankan kebijakan. Sehingga kondisi ini tidak mempengaruhi keberlangsungan aktifitas di Kawasan tersebut. Permasalahan ini juga harus disikapi dengan bijak oleh seluruh elemen agar proses pelaksanaannya dapat berlangsung baik dan dengan koordinasi yang baik pula.

\section{Strategi yang digunakan}

Strategi yang digunakan pada kebijakan minopolitan yang telah ada di daerah ini menurut penulis cukup baik. Dinamika yang terjadi di lapangan cukup terukur sehingga kondisi masyarakat saat ini telah cukup mandiri dan terarah dalam mengimplemantasikan konsep Kawasan minapolitan yang ada. Kondisi ini dapat penulis asumsikan sebagai keberhasilan pada masa yang lalu dengan seluruh pihak yang terlibat. Namun secara kualitas nya, strategi yang ada perlu di rubah menyesuaikan dengan dinamika yang ada di lapangan. Hal ini cukup terlihat jelas ketika masyarakat di Kawasan tersebut saat ini tidak menghasilkan sebuah inovasi yang baru sesuai konsep minapolitan. Masyarakat saat ini bahkan melaksanakan sebuah konsep desa wisata yang menurut penulis cukup baik namun kurang perhatian pemerintah sehingga masyarakat melakukan kerjasama dengan pihak ketiga yaitu swasta. strategi yang dilakukan masih sebatas jumlah produksi dan mengurangi biaya operasional. Kondisi ini menurut penulis merupakan sebuah fenomena yang baik namun secara evaluasi kebijakan hal ini harus dapat di rubah dengan menyertakan pemerintah dalam menetapkan strategi dengan menentukan jangka waktu dari pendek, menengah hingga Panjang.

\subsection{Faktor-faktor yang mempengaruhi Kebijakan Inovasi Teknologi Bidang Perikanan bagi Masyarakat Transmigrasi Lokal di Kecamatan XIII Koto Kampar Kabupaten Kampar}

Dapat penulis simpulkan masih belum maksimal. Kebijakan Kawasan minopolitan Bidang Perikanan bagi Masyarakat Transmigrasi Lokal di Kecamatan XIII Koto Kampar Kabupaten Kampar yang belum terlaksana dengan baik namun penulis identifikasikan dengan 2 faktor yaitu faktor pendukung dan faktor penghambatnya.

\section{Faktor Pendukung}

\section{Konsep awal kebijakan}

Kondisi awal Kawasan minopolitan yang benar-benar direncanakan dengan sedemikian rupa telah membentuk sebuah konsep awal yang cukup baik dalam pelaksanaan kebijakaannya. Faktor ini penulis identifikasikan sebagai faktor pendukung karena dinamika yang terjadi saat ini cukuplah tinggi namun 
para pihak terkait tetap berada pada kondisi dimana mengacu kepada konsep awal kebijakan. Sehingga hal ini menjadi penyeimbang manakala dinamika tidak dapat lagi di kendalikan.

\section{Sumber daya}

Ketersediaan sumber daya baik alam dan manusia telah berhasil menjadi dukungan yang sangat luar biasa bagi keberlangsungan kebijakan ini. Kondisi ini menjadi sebuah hal yang harus dipertahankan karena berdampak langsung terhadap keberlangsungan kebijakan. Sumber daya juga harus dapat di organisir secara baik dan terukur agar kondisi di masa - masa selanjutnya dapat berjalan sesuai harapan dan tetap berada pada kondisi dimana sumber daya tersedia dan siap untuk digunakan.

\section{Kemandirian masyarakat pembudidaya}

Sifat mandiri yang terbentuk pada masyarakat telah berhasil mendorong progress dari kebijakan. Kondisi ini dapat dilihat dari hasil wawancara penulis dimana masyarakat tetap mandiri walaupun peran dari pemerintah tidak sesuai harapan. Peran pemerintah di masa lalu yang merangkul serta menempatkan praktisi-praktisi serta pendamping lapangan kepada masyarakat yang saat ini telah menjadi pembudidaya sangatlah terlihat. Peran praktisi-praktisi tersebut bahkan saat ini tergantikan oleh mereka yang dulu duduk di kursi pendengar yakni masyarakat yang saat ini menjadi pembudidaya. Pola pikir yang dibentuk dengan merangkul dengan cara memberi bukti berupa success story juga telah membentuk mentalitas positif pada masyarakat sehingga hal ini menjadi salah satu faktor pendukung.

\section{Faktor Penghambat}

\section{Peran Pemerintah}

Peran pemerintah sangatlah penting dalam menjalankan sebuah kebijakan yang ada. Peran pemerintah pada kebijakan minapolitan yang penulis amati dalam penelitian ini dapat dikatakan cukup pasif dan tidak terukur. Fenomena ini bersamaan dengan dinamika birokrasi yang terjadi pada masa lalu dan menyebabkan perubahan yang cukup berdampak pada kebijakan minapolitan ini sendiri. Hal ini sangatlah disayangkan karena terkesan dibiarkan terjadi. Padahal, pemerintah seharusnya bertanggung jawab penuh hingga target yang diharapkan tercapai secara maksimal.

\section{Komunikasi dan koordinasi birokrasi}

Fenomena yang penulis amati dilapangan terkait faktor ini sangatlah kompleks. Potret birokrasi yang syarat oligarki kerap kali mempegaruhi kualitas SDM terkait. Dampak yang terjadi adalah ketidak mampuan mengemban jabatan yang mengakibatkan komunikasi dan koordinasi birokrasi antar lini tidak maksimal. Sangat mengejutkan ketika penulis bertanya tentang bagaimana hal ini dapat terjadi ketika sebuah kebijakan yang dapat dikatakan sangat bagus tidak dapar berjalan maksimal karena kepentingan segelintir orang. Hal ini menurut penulis dapat menjadi bom waktu yang sangat mengkhawatirkan karena tidak menempatkan orang pada posisi yang tepat adalah sebuah fenomena yang dianggap lumrah di masa kini. Walaupun penyesuaian dapat dilakukan seiring waktu berjalan, kedewasaan birokrasi penting di kedepankan agar dapat berjalan sesuai harapan seluruh pihak terkait. Sehingga komunikasi dan koordinasi birokrasi dari tingkat akar hingga pucuk dapat berlangsung maksimal dan menuju ke arah yang lebih baik lagi.

\section{Evaluasi jangka waktu}

Proses lahirnya kebijakan sudah pasti memiliki target yang akan dicapai. Tidak adanya evaluasi jangka waktu yang dilakukan menjadi salah satu faktor penghambat. Evaluasi jangka waktu yang penulis maksudkan adalah dengan menetapkan jangka waktu terhadap pelaksanaan kegiatan minopolitan di lapangan dan dilakukan evaluasi dengan capaian yang diharapkan. Hal ini sangatlah penting mengingat dari awal waktu ditetapkannya kebijakan ini kondisi dilapangan tidak menunjukan perkembangan yang signifikan dari masa-masa sebelumya. Terdapatnya evaluasi jangka waktu dengan beragam indikator yang di evaluasi juga menurut penulis akan meminimalisir perubahan terhadap pelaksanaan terkait kebijakan ini. Kondisi ini juga akan mengintegrasikan aktifitas yang terjadi di seluruh Kawasan minopolitan sehingga dapat diukur secara pasti serta dasar evaluasi tersebut. 


\section{KESIMPULAN}

Peneliti menyimpulkam bahwa Kebijakan inovasi teknologi bidang perikanan bagi masyarakat transmigrasi lokal di kecamatan XIII Koto Kampar Kabupaten Kampar sebagai kawasan sentra produksi perikanan di provinsi Riau melalui surat Keputusan Gubernur Riau No. KPTS/99/II/2000 tanggal 28 Februari 2000 dan baru tahun 2010 ditetapkan sebagai kawasan Minapolitan. Kemudian Keputusan Menteri Kelautan dan Perikanan RI No. Keputusan 32/Men/2010 menyatakan penampatan kawasan Minapolitan di provinsi Riau berada di Kabupaten Kampar yang dipusatkan pada wilayah Kecamatan XIII Koto Kampar. Undang-undang Nomor 12 tahun 1956 tentang Pembentukan Daerah Otonomi Kabupaten dalam lingkungan daerah provinsi Sumatera Tengah. Visi pembangunan Kabupaten Kampar adalah "Terwujudnya Kabupaten Kampar sebagai Pusat Agribisnis dalam Lingkungan Masyarakat yang Berbudaya, Sejahtera, dan Agamis". Dalam rangka merealisasikan visi tersebut ditetapkan salah satu misi pembangunan Kabupaten Kampar yakni "Mengoptimalkan pengelolaan dan pemanfaatan sumberdaya alam yang berwawasan lingkungan". Pengembangan kawasan Minapolitan dapat dijadikan salah satu alternative solusi dalam mewujudkan visi dan misi Kabupaten Kampar tersebut. Pelaksanaan Kebijakan inovasi teknologi bidang perikanan bagi masyarakat transmigrasi lokal di kecamatan XIII Koto Kampar Kabupaten Kampar menurut penulis memiliki faktor pendukung dan faktor penghambatnya. Faktor pendukung yaitu : konsep awal kebijakan, sumber daya dan kemandirian masyarakat pembudidaya. Faktor penghambat yaitu: peran pemerintah, koordinasi dan komunikasi birokrasi, dan evaluasi jangka waktu maka tujuan dari pelaksanaan kebijakan ini masih belum dapat tercapai dengan maksimal.

Pada prinsipnya, kebijakan ini apabila dilaksanakan dengan baik dapat mencapai target yang di harapkan. Sehingga dapat penulis sarankan kebijakan ini dapat dilanjutkan dengan adanya beberapa perbaikan. Karena terdapatnya beberapa faktor yang menjadi penghambat pelaksanaan program, maka dapat penulis berikan beberapa saran untuk memperbaiki pelaksanaan kebijakan Kebijakan inovasi teknologi bidang perikanan bagi masyarakat transmigrasi lokal di kecamatan XIII Koto Kampar Kabupaten Kampar sebagai berikut :

1. Disarankan kepada pihak desa, kecamatan, kabupaten dan provinsi sebagai implementor kebijakan untuk lebih meningkatkan perhatian terhadap kondisi di lapangan serta memperbaiki alur komunikasi dan koordinasi agar terfokus kepada hasil yang diharapkan.

2. Disarankan kepada kementerian kelautan dan perikanan untuk melakukan audit menyeluruh terhadap pelaksanaan Kawasan minapolitan di kecamatan XIII Koto Kampar Kabupaten Kampar agar dapat menemukan permasalahan yang menyebabkan kurangnya perhatian pemerintah terhadap kebijakan ini dan kemudian mengeluarkan rekomendasi terhadap temuan tersebut untuk ditindak lanjuti sesegera mungkin.

3. Disarankan kepada masyarakat pembudidaya dan secara umum masyarakat di Kawasan minapolitan untuk melakukan advokasi dan desakan dengan tekanan terhadap pemerintah maupun pihak manapun apabila menemukan kesalahan atau kekurangan dalam aktifitas nya pada wilayah Kawasan minapolitan. Masyarakat lokal merupakan pihak orisinil dari berjalannya kebijakan ini sehingga memiliki pengetahuan dan hak serta kewajiban untuk menjaga, melestarikan dan mengembangkan Kawasan minapolitan di kecamatan XIII Koto Kampar Kabupaten Kamp 


\section{DAFTAR PUSTAKA}

[1] Abidin, Said Zainal. 2006. Kebijakan Publik. Jakarta : Suara Bebas

[2] Ancok, D, 2012. Psikologi Kepemimpinan dan Inovasi. Jakarta: Erlangga

[3] Bungin, Burhan. 2011. Penelitian Kualitatif : Komunikasi, Ekonomi, Kebijakan Publik dan Ilmu Sosial Lainnya Edisi Kedua. Jakarta: Kencana Prenada Media Group.

[4] Dunn, Peter A, 1997. Government Policy Innovations and Trends in barrier-free housing, accessible Transportation and Personal Support, Canadian Journal of Rehabilitation, Volume 10, No.2

[5] Emzir, Prof. Dr. M.Pd. 2012. Metodologi Penelitian Kualitatif : Analisis Data. Jakarta: Raja Grafindo Persada.

[6] Everett M. Rogers dan F. Floyd Shoemaker. 1981. Memasyarakatkan Ide-ide Baru : Penyusun Abdillah Hanafi. Surabaya : Penerbit Usaha Nasional.

[7] Keputusan Menteri Kelautan dan Perikanan Republik Indonesia Nomor: 35/Kepmen-KP/2013 tentang Penetapan Kawasan Minapolitan

[8] Halvorsen, Thomas, et al. 2005. On the Differences between Public and Private Sector Innovations. Oslo : Publin Report.

[9] Hubbies. 2005. Manajemen kreativitas dan inovasi dalam bisnis. Jakarta : Hecca Mitra Utama.

[10] Nazir, Moh, 2009. Metode Penelitian. Jakarta : Ghalia Indonesia.

[11] Surat Keputusan Gubernur Riau No. KPTS/99/II/2000 tanggal 28 Februari 2000

[12] Undang-undang Nomor 12 tahun 1956 tentang Pembentukan Daerah Otonomi Kabupaten dalam lingkungan daerah provinsi Sumatera Tengah.

[13] Undang-Undang No. 26 Tahun 2007 tentang Penataan Ruang 